は同一重量百分比のアルミナ添加より大である。 本研究の費用の一部衣文部省科學研究費による。

耐水性は酸化》ロム添加により改善され，その效果

$(8 / 5 / 51$ 受附 $)$

は添加量重量百分比で $3 \%$ 以上で著しい。

\title{
珐瑯嬏の熔融における弗素の逃散
}

\author{
永井彰一郎・井本文夫・山添重治 \\ (東京大學工學部應用化學科)
}

\section{Escape of Fluorine during Smelting of Porcelain Enamel Frit.}

By Shoichiro NAGAI, Fumio IMOTO and Shigeharu YAMAZOE

Considering the trend of the frit composition of today towards softer, selected three ground glasses (Fig. 1) and added tenth of sodium fluoride and sodium silicofluoride respectively: By means of the heat balance, it was known the carbonic acid gas exhausting reaction in fluorine containing batches begins at about $120^{\circ} \mathrm{C}$ lower and ends at about $80^{\circ} \mathrm{C}$ lower temperature than that of fluorineless batches. The difference of effect was scarcely found between two fluorides.

$100 \mathrm{~g}$ batch of each was smelted in platinum basin, weight loss measured, chemically analysed from which escaping forms were deduced as just melted down and melted on as long as three hours. While in the former fluorine loss was attsibuted to $\mathrm{NaF}$ and $\mathrm{F}_{2}$ (conveniently represents fluorine loss which accompanies no cation) for the most, $\mathrm{SiF}_{4}$ for only one case, in the latter in no case to $\mathrm{SiF}_{4}$.

In smelting of moderne type of titanium frit on plant scale, fluorine loss amounts to $15 \sim 20 \%$ and its increase with smelting period was relatively small reversely to the above mentioned results.

I. 緒 言

珐瑯婇の調合には通列 5 ～12\%の弗素化合物が用い られ，從つてガラス化成分中には 3〜8\% の弗素が含 まれている。このるのは熔劑として並びに基碟乳白劑 としての効果を有する他, workability の附與に缺く ことの出來ないものとされている。古來ガラス類の熔 融に乱壮る弗素分の揮散については次に述べるように いくつかの報告が見られるが, 最近では釉組成がかな り變化して招り，か上うな組成に對してその逃散狀況 が充分明かではないので，弗素ガラス類を取扱らに賞 つて亦づ弗素の揮散についての正確な概念を得ておく ことが必要である。

\section{II. 概 往の交献}

Blau(1) は $\mathrm{SiO}_{2}$ 74.3, $\mathrm{Na}_{2} \mathrm{O}$ 15.2, $\mathrm{CaO}$ 10.5\%な

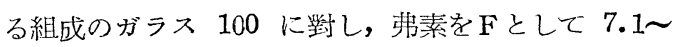
12.6を添加した場合に何れるほ心゙ $70 \%$ の弗素が失わ れることを認めた。分析結果によればこの中 $15 \%$ が
$\mathrm{SiF}_{4}$ の形で約 $5 \%$ $\mathrm{Ca}$ 抢よび $\mathrm{Na}$ に伴わ扎て，し かして残部は何らか別の形で失われたと考えられる。 但し弗素源として弗化ナトリウムと溃石 $\left(\mathrm{CaF}_{2}\right)$ とを 用い，調合に扔いてそれぞれ當量のソーダ灰と白峛と を減ずることは勿論である。Bock(2)，Vogt( ${ }^{(3)}$ 等は更 に弗損の大きいことを報じているが，熔融條件は何れ 子異る。

Agde, Krause(4) は $\mathrm{SiO}_{2}$ 52.59, $\mathrm{Na}_{2} \mathrm{O} 41.83, \mathrm{~F}$ $9.64 \%$ なる組成のガラスで $17.4 \%$ の弗損を認めた。 その中の約半量は $\mathrm{SiF}_{4}$ として，他のほとんどすべて は恐らく Naに伴われて逃げると考光られ，它狄以外 の形の逃散は考学る必要がない。何となればアルカリ 減の弗素當量が充分大きいからである。彼らはこの他 $\mathrm{Al}_{2} \mathrm{O}_{3}$ と $\mathrm{B}_{2} \mathrm{O}_{3}$ との一方, 文は兩方を含む多數の釉で 14 34\% の弗損值を得，組成との間に何等か定量的 な關係を見出气うとしたが確からしい關係が得られな かつた。

E. Mushiol(5)によれば $\mathrm{SiO}_{2} 56.3, \mathrm{~B}_{2} \mathrm{O}_{3} 9.1, \mathrm{Al}_{2} \mathrm{O}$ 
11.3, $\mathrm{CaO} 0.3, \mathrm{MgO} 0.6, \mathrm{Na}_{2} \mathrm{O}$ 19.5, F 10.4\%な る硬タイプのガラスでは熔融の初期にもかなりの弗損 (最終值の約 $1 / 3$ ) があるが，後期にもな擆しい減 少が見られるのに反し， $\mathrm{SiO}_{2} 45.5, \mathrm{~B}_{2} \mathrm{O}_{3} 10.3, \mathrm{Al}_{2} \mathrm{O}_{3}$ 11.7, $\mathrm{CaO} 3.7, \mathrm{MgO} 0.9, \mathrm{Na}_{2} \mathrm{O} 21.3, \mathrm{~F} 11.8 \%$ 。な る軟タイプのガラスでは初期に特に多( (最終值の $2 / 3$ ) 失われる。しかし何れも 24 時間後にはほよ゙ $70 \%$ に 收歛することが報ぜられている。

Meyer, Havas ${ }^{(6)}$ は普通の珐玨粙の上下 3 種類づつ について 12〜24\% の弗損を認め，その實驗範圍では 酸性成分對鹽基性分のモル比と弗損との關係がほが比 例していることを述べた。

使用する弗化物原料による逃散の難易については Vielhaber(7) と Havas( ${ }^{(8)}$ との結果がほが一致してい るので，その傾向は一應信賴するに足ると考えられ る。即ち前者では $\mathrm{AlF}_{3}>\mathrm{SiF}_{4}>\mathrm{CaF}_{2}>\mathrm{Na}_{3} \mathrm{AlF}_{6}>$ $\mathrm{NaF}$, 後者では $\mathrm{AlF}_{3}>\mathrm{CaF}_{2}>$ 水晶石 (Cryolite) $\mathrm{NaF}$ 、で㟧つて弗化ナトリゥムが最子安定である。

この他詳細については引照交献 (10)を見られた い。

\section{III. 原料および調合}

調合には珪石の他は化學藥品を用い，炭酸ナトリゥ ムの純分はその都度決定した。珪石の高品位のものを 㽉酸で長時間煮沸處理, 水洗乾燥してシリカ原料とし た。即ち $99.65 \% \mathrm{SiO}_{2}, 0.35 \% \mathrm{Al}_{2} \mathrm{O}_{3}$ その他の組成 を持つ，。

基礎ガラスの選定に當つては, 從來の文献にある下 釉組成を多數參照し, 便宜上 ${ }^{\prime} \mathrm{Al}_{2} \mathrm{O}_{3}$ を $\mathrm{SiO}_{2}$ に, 愹融 劑をすべて $\mathrm{Na}_{2} \mathrm{O}$ に含有せしめて $\mathrm{Na}_{2} \mathrm{O}-\mathrm{SiO}_{2}-\mathrm{B}_{2} \mathrm{O}_{3}$ 三 成分系圖上 (第 1 圖) に求めると斜線部の範圍に收末 るが，その牙仲心を $\mathrm{A} \quad\left(\mathrm{Na}_{2} \mathrm{O} 20, \mathrm{SiO}_{2} 65, \mathrm{~B}_{2} \mathrm{O}_{3}\right.$
15\%)とする。上釉では $\mathrm{Na}_{2} \mathrm{O}$ 含量がこれよりや〉高 く，下釉でも實用品は比較的軟かくなつている。文最 近の再結晶乳白珐瑯では $\mathrm{B}_{2} \mathrm{O}_{3}$ 含量が著しく高くなつ たことは周知の通りである。よつてそれらの極端なる のとして $\mathrm{B}\left(\mathrm{Na}_{2} \mathrm{O} 35, \mathrm{SiO}_{2} 55, \mathrm{~B}_{2} \mathrm{O}_{3} 10 \%\right)$ 抢よび $\mathrm{C}\left(\mathrm{Na}_{2} \mathrm{O} 30, \mathrm{SiO}_{2} 45, \mathrm{~B}_{2} \mathrm{O}_{3} 25 \%\right)$ を選んだ。各原 料を精密に調合して充分混合し，それぞれを三等分し て無弗素バッチ A， B，C と备に弗化トリゥム抽よび 策1 圆 代表的嬏組成

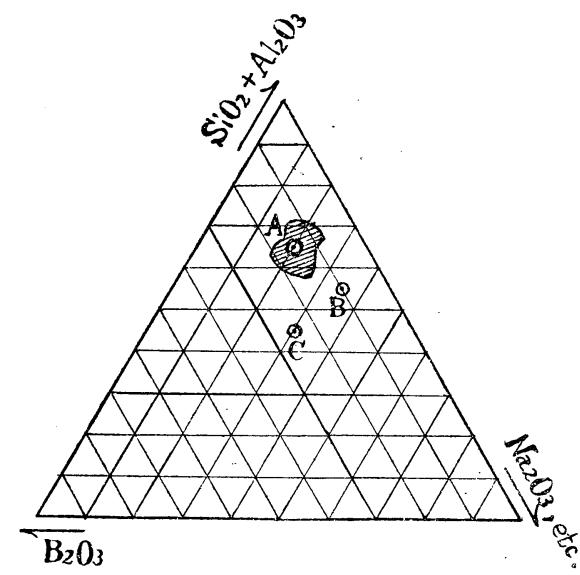

珪弗化ナトリウムをガラス化重量の 100 に對してそれ ぞれ 10 を加壳たバッチ $\mathrm{A}+\mathrm{F}, \mathrm{B}+\mathrm{F}, \mathrm{C}+\mathrm{F}$ 抢よび $\mathrm{A}+\mathrm{S}, \mathrm{B}+\mathrm{S}, \mathrm{C}+\mathrm{S}$ を得る(第 1 表參照)。

\section{IV. 噍 備 實 驗}

基礎嬏のガラス化重量の $1 \mathrm{~g}$ に相當するだけ各調合” 物より採り，白金ルッボで熱天科を用いて重量減を追 究して第 2 圖の曲線を得た（温度上昇は $5^{\circ} \mathrm{C} / \mathrm{min}$ )。

第1表 調合組成と熔融における重量減

調

垚石，嘲砂 ソーダ质 弗化物 計

A $\quad 65.00 \quad 41.00 \quad 24.60$

B $\quad 55.00 \quad 27.30 \quad 58.40$

C $\quad 45.00 \quad 68.30 \quad 36.10$

$\mathrm{A}+\mathrm{N} 65.00 \quad 41.00 \quad 24.60$

$\mathrm{B}+\mathrm{N} 55.00 \quad 27.30 \quad 58.40$

$\mathrm{C}+\mathrm{N} 45.00 \quad 68.80 \quad 36.10$

理弗化ナトリウム

$\begin{array}{llllll}\mathrm{A}+\mathrm{S} & 65.13 & 41.34 & 23.93 & 10.00 & 140.38\end{array}$

$\begin{array}{lllllll}\mathrm{B}+\mathrm{S} & 55.13 & 27.55 & 54.92 & 10.00 & 147.58\end{array}$

$\begin{array}{llllll}\mathrm{C}+\mathrm{S} & 45.07 & 68.87 & 33.89 & 10.00 & 157.83\end{array}$
熔融後

重訫算值)

99.61

99.79

100.08

109.61

109.99

110.08

109.75

108.95

109.94
·宫測重量(歩止り) ガラス化直後 同 3 時間後

99.26

99.94

99.83

109. 19

109.88

109.69

109.26

108.74

109. 39
V. 本實驗操作お よび實驗結果

ガラス化重量の $100 \mathrm{~g}$ に相當するバ ッチを白金皿に採り 炭化珠素發熱體電氣 爐を用いて $1150^{\circ} \mathrm{Cで}$ 熔融する。ガラス化 直後预よびガラス化 後 3 時間に打ける重 量減を冷後の科量に よつて決定し，他方 
各ガラスを全分析に附する。弗素は弗化カルシウム法 により,アルカリは Laurence Smith 氏法により，

第 2 圖 熱天科に上る減量曲線

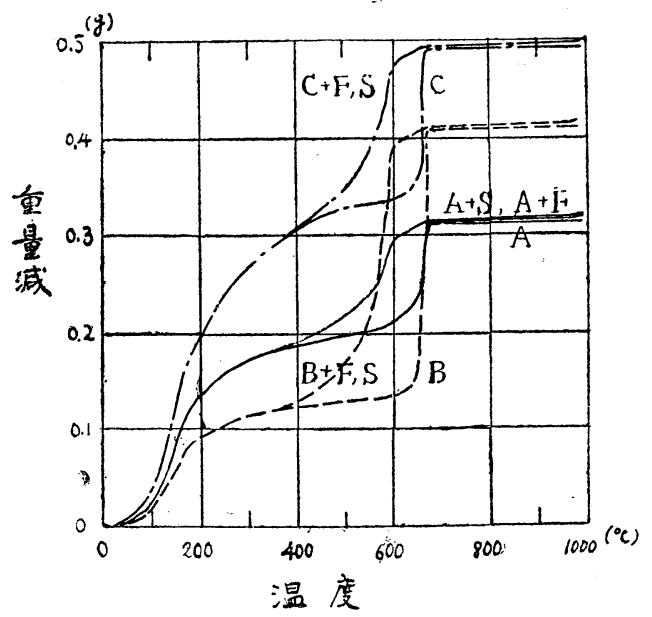

又硼酸は Jorgense 氏法によりそれぞれ分析した。 第 1 表には重量減即ち愹融に抢ける歩止りを, 第 2 表 には分析值と計算組成とを比較して弗素の逃散率とそ の逃散形式とを求める計算例を示す。

最後に 70 斤るつぼを用い, 工場規模で熔融したチ タニウム婇について弗素減を分析した結果を第4 表に 示す。この釉組成は Friedberrg 等(9)の Y-12 をいく らか改良したもので, 珪石, 矹砂, チタニア, チリ硝石, 硝石扔よび珪弗化ナトリウムを用いて調合した。筆等
第 3 表 弗素の可能な逃散形式と郴損率

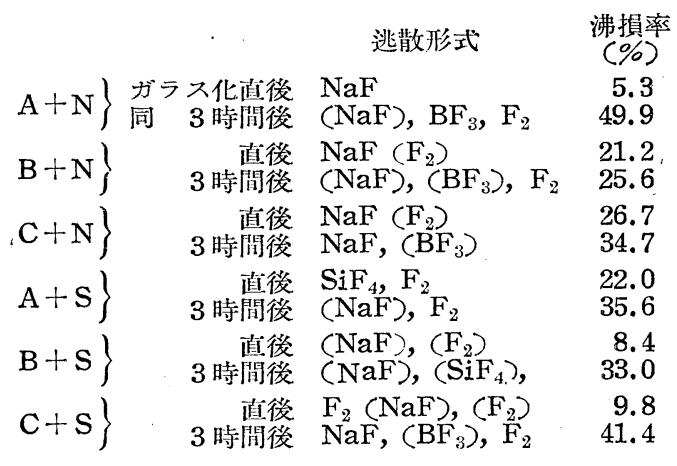

第4 表 チタニウム釉の弗素減 (附 Y-12)

\begin{tabular}{lcccc} 
熔融時閪 $(\mathrm{hr})$ & 4 & 5 & 6 & 7 \\
分析 值 $(\%)$ & 4.26 & 4.20 & 4.10 & 4.08 \\
減 率 $(\%)$ & 14.8 & {$[6.0$} & 19.6 & 18.4 \\
\hline
\end{tabular}

$\mathrm{Y}-12\left(\mathrm{Na}_{2} \mathrm{O} 10.5, \mathrm{~K}_{2} \mathrm{O} 3.5, \mathrm{SiO}_{2} 45.0, \mathrm{TiO}_{2} 18.0\right.$ F 5.0)

等の精密な補正計算によれば計算弗素量は $5.1 \%$ であ る。

\section{考察}

まづ第 2 圖を見ると・第一段の硼砂の脱水がほ 了した後 $500^{\circ} \mathrm{C}$ 附近に始まり $700^{\circ} \mathrm{C}$ 附近に終る宸 酸ガス放出の段階がある。無弗素釉ではこの第二段の 万は比較的鋭い階段狀をしているが，この反應は弗化 物を加えることによつて前者に比して約 $120^{\circ} \mathrm{C}$ だけ 低温部に始まり，約 $80^{\circ} \mathrm{C}$ だけ低温部で完結してい

第 2 表 各成分の選散情況 (一例) 1

\begin{tabular}{|c|c|c|c|c|c|c|c|c|c|}
\hline \multirow[b]{2}{*}{$(\mathrm{C}+\mathrm{S})$} & \multirow[b]{2}{*}{ 計算組成 } & \multicolumn{3}{|c|}{ ガラス化直後 } & \multicolumn{3}{|c|}{ 同 3 時閒後 } & \multirow[b]{2}{*}{$\begin{array}{l}\text { 全差沸 } \\
\text { 素當 }\end{array}$} & \multirow[b]{2}{*}{$\begin{array}{l}\text { 可能な選 } \\
\text { 散形式 }\end{array}$} \\
\hline & & 分析組成 & 同補正值 & 増 減 & 分析組成 & 同補正值 & 増 減 & & \\
\hline $\mathrm{Na}_{2} \mathrm{O}$ & 32.94 & 29.82 & 32.60 & -0.34 & 28.52 & 30.42 & -2.18 & -1.55 & $\mathrm{NaF}$ \\
\hline $\mathrm{SiO}_{2}+\mathrm{Al}_{2} \mathrm{O}_{3}$ & 48.27 & 44.30 . & 48.44 & +0.17 & 46.62 & 49.65 & +1.21 & & \\
\hline $\mathrm{B}_{2} \mathrm{O}_{3}$ & 25.23 & $23.03^{\circ}$ & 25.20 & -0.03 & 23.48 & 25.02 & -0.18 & -0.17 & \\
\hline $\mathrm{F}$ & 6.04 & 4.98 & 5.45 & -0.59 & 2.77 & 2.95 & -2.50 & -3.09 & $F_{\Sigma}$ \\
\hline $\mathrm{O}$ & 2.54 & 2.10 & 2.30 & II & 1.17 & [. 24 & . $\|$ & $\|$ & \\
\hline 計 & 109.94 & 100.03 & 109.39 & $0.8 \%$ 損失 & 100.25 & 106.80 & $41.4 \%$ 損失 & $51.2 \%$ 提 & \\
\hline 歩止り & & 109.39 & & & 106.80 & & & & \\
\hline
\end{tabular}

第 2 表 各成分の逃散情況 (一例) 2

ガラス化直後

(C) 計算組成 分析組成, 同補正值 增 減

\begin{tabular}{|c|c|c|}
\hline 分析組成 & 同補正值 & 増 減 \\
\hline 28.40 & 28.29 & -1.00 \\
\hline 46.17 & 45.98 & +0.75 \\
\hline 24.73 & $24 \cdot 64$ & -0.97 \\
\hline 99.27 & 98.91 & \\
\hline 98.91 & & \\
\hline
\end{tabular}


る。これは恐らく連鎖反應的に生成寸る兩性の弗化物 によつて嗍珠酸ナトリウムガラスの生成が促進される ためであろら。その場合曲線の屈曲部が至極緩慢にな つているのは當然浓想されることである。興味むるの は弗化ナトリウムと珪弗化ナトリウムの反應促進作用 にはほとんど差異が認められないことで，たがシリカ に富むガラスAに招いては僅かに後者の方が咸量絶對 值を增して扔り，高温で为漸次々の傾向か認められる に過ぎない。(A+S 類の調合に抢ける炭酸ソーダの 純度の相違は補正してある)。從つてO. Kerstan(7)の 報告のように珪弗化ナトリウム釉では約半量の弗素が

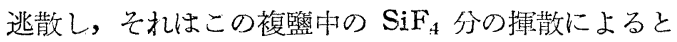
簡單に考学るのは誤りである。上に述べたような弗化 物の性質は，固相で炭酸ガスを放出せしめるのに役立 つので，バッチ溢出の防止に效果がある。

次に重量減を問題にする場合には第1 表にあげたガ ラス化重量並びに熔融に扔ける歩止りが組成の合計に なるよらに各成分を比例配分しなければなら呚第 2 表にはその補正計算の一部を示したわけである。金屬 をすべてその酸化物として表し，弗素を單獨に F とし て表す方法はガラスのように弗素が特定のイオンのみ に制約されない場合に好都合であるが，その場合の合 計は弗素と當量の酸素量げけ過剩になつているわけで ある。表中○の行はこれに當り，合計の際にその值は 負になることに注意を要する。從つて第 4 表に示した Y-12 のような組成の表現は賽用的なるので嚴密には 正しくない。第 6 欄の全差弗素當量の列を見るに $\mathrm{Na}$ と B との減少が全部 $\mathrm{F}$ 伴つて逃散したとしてもその 弗素賞量は 1.72 であつて，な押全弗損 3.09 の約半 量に過ぎない。まして同表下部の無弗素釉Cに揓ける アルカリ減もかなり大きいので，含弗釉に劣いて實際 Fを伴なら Naはもつと少いと考光ねばならない。從 つて半分以上の弗素損は金屬カナオンを伴わない $\mathrm{HF}, \mathrm{F}_{2}, \mathrm{FO}_{2}, \mathrm{~F}$ などの形が㫴らられるが，检定の手 段がないので便宜上單獨逃散として次の第 3 表には單 に $\mathrm{F}_{2}$ と記述した。太字は大量に期待される逃散形式 であり括弧を附したのは極く微量がその逃散に歸せら れる場合である。ガラス化以前即ち主として固棚反應 に際してはほとんどの場合 $\mathrm{NaF}$ と單獨の逃散とがあ り，僅かにシリカ量が多く，弗素源として珪弗化ナト リウムを用いた $\mathrm{A}+\mathrm{S}$ の場合だけ $\mathrm{NaF}$ の代りに $\mathrm{SiF}_{4}$ が考觉られる。これに對してガラス化後にはやはり $\mathrm{NaF}$ の逃散がある他，單獨逃散がより支配的となる。 弗損率は概してガラス化の前に少く後に多く, 又何れ
も 40 60\% の大量に達しているが，これは實驗條件 が特殊であること, 即ちバッチが小量であり, 熱傳導 の良い白金皿を用いて和り，上面が廣く開いているた め極端に揮散を容易にした結果になつていることを考 慮せ权ばなら双實際の場合は原料が固態的るいは半 固態で存在する期間汭非常に長く, 密閉した肉厚のる つぼを用いるので水蒸氣の叠找作用などが著しく, 從 つてガラス化前の逃散が大きいと考学られる。

第 4 表によ狆ば市販チタニウム釉は最適熔融條件で はその弗素減が 15〜20\%で，ガラス化後の時間經過 による弗損率の增加は比較的小さいことが分る。

\section{結語}

普通の珐瑯粙組成に近い3 種の方ラスを $\mathrm{Na}_{2} \mathrm{O}$ $\mathrm{SiO}_{2}-\mathrm{B}_{2} \mathrm{O}_{3}$ 三成分系圖上に選び，熔融條件は普通珪瑯 のそれに，又逃散條件をより苛酷にして，ガラス化前 後弗素逃散狀況を檢討し， $\mathrm{SiF}_{4}, \mathrm{BF}_{3}$ などの形で逃 散することは少く, NaF の形と, 金屬カチオンを伴 わない形による逃散が大部分で，特にガラス化後に第 三の形式が多いととを認めた。

往年の珠瑯組成とかなり異つている現今のチタニウ ム釉を工場規模で熔融した場合にはやはりこれまでの ものと同樣 15 20\% の弗素逃散率があり，ガラス化 後の逃散はこの場合には比較的少い。

交献回顧に阷いて概待の報交をまとめて弗素逃散に 關する概念の把握に資した。

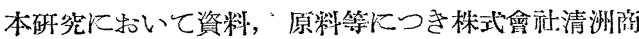
占並びに 保土ケ谷化學工業株式會部より便宣を受けた ととを附記して謝意を表します。

\section{引照 交 献}

(1) H. H. Blau: Ind. Eng. Chem., 1934, 26 , (10), 1060 62

(2) B. Bock: Sprechsaal, 1908, 41, (40), 552

(3) G. Vogt: 7th International Congr. of Inorg. Chem., London, 1909

(4) G. Agde and H. F. Krause: Z. Angew. Chem., 1927, 49, 826

(5) E. Mushiol: Keram. Rund., 1926, 34, 53

(6) M. Meyer and B. Havas: Sprechsaal, 1909, 42, (31), 460; 1911, 44, (1), 6

(7) L. Vielhaber: Eimaluaren Ind., 1938, 15 , (37), 247

(8) B. Havas: Diss., T. H. Karlsrube, 1910

(9) A. L. Friedberg and F. A. Petersen: $J$. Am. Ceram. Soc., 1950, 33, (1), 17; Finish, 1949, June, 44.

（10）永井，井本：班㰾工業，昭25，3，(9)，1７ 